TAO, Vol. 16, No. 3, 563-577, August 2005

\title{
Preliminary Results from Seismic Monitoring at the Tatun Volcanic Area of Northern Taiwan
}

\author{
Cheng-Horng Lin ${ }^{1, *}$, Konstantinos I. Konstantinou ${ }^{1}$, Hsin-Chieh Pư ${ }^{2}$, Chia-Chi Hsu ${ }^{3}$, Yu-Mei Lin ${ }^{4}$, \\ Shuei-Huei You ${ }^{4}$ and Yuan-Ping Huang ${ }^{4}$
}

(Manuscript received 6 April 2004, in final form 11 June 2005)

\begin{abstract}
To enhance our understanding of the seismic characteristics of the Tatun volcanic area, a small aperture seismic array consisting of 5 seismic stations has been deployed in the area since May 2003. Each of the seismic stations was installed with both short-period and broadband sensors to record micro-earthquakes as well as long-period volcanic tremors. The preliminary results of the seismic monitoring of the Tatun volcanic area show a large number of shallow micro-earthquakes clustered beneath the Chihsingshan volcano and Tayoikeng areas. Among these, some swarms were also detected. Intensifying the issue further, some complex seismograms with harmonic codas and seismic tremors have been identified. Considerable crustal heterogeneity in the Tatun volcanic area is indicated by the presence of strong coda waves. Combining our findings with other geological and geochemical observations, we postulate that volcanic activities might not be totally extinct in the Tatun volcanic area. Thus, further investigations of Tatun volcanic area ought be conducted to examine the possibility of such potential volcanic activity.
\end{abstract}

(Key words: Tatun volcano, Seismicity, Swarm, Volcanic tremor)

\section{INTRODUCTION}

The Tatun volcanic group, which includes more than 20 volcanoes (Chen and Wu 1971;

\footnotetext{
${ }^{1}$ Institute of Earth Sciences, Academia Sinica, Taipei, Taiwan, ROC

2 Institute of Geophysics, National Central University, Chung-Li, Taiwan, ROC

3 Dept. of Earth Sciences, National Cheng-Kung University, Tainan, Taiwan, ROC

${ }^{4}$ Dept. of Earth Sciences, National Taiwan Normal University, Taipei, Taiwan, ROC

* Corresponding author address. Dr. Cheng Horng Lin, Institute of Earth Sciences, Academia Sinica, Taipei, Taiwan, ROC; E-mail: lin@earth.sinica.edu.tw
} 
Wang and Chen 1990), is located on the northernmost tip of Taiwan (Fig. 1). It is just north of the Taipei basin, the capital of Taiwan with a total population of more than seven million inhabitants. One of the major geological structures in the Tatun volcanic group is the Chinshan fault, which is a reverse fault and strikes in the NE-SW direction. The southwestern extension of this fault might be connected to the Hsinchun fault beneath the western Taipei basin. Based on the K-Ar dating (Juang and Chen 1989; Tsao 1994) and fission track analyses (Wang and Chen 1990), the eruption history of the Tatun area can be divided into two major periods. As for the first, the major eruption was around $2.5-2.8 \mathrm{Ma}$, whereas the second started in $1.5 \mathrm{Ma}$ and continued until the last eruption around 0.1 - 0.2 Ma (Song et al. 2000a).
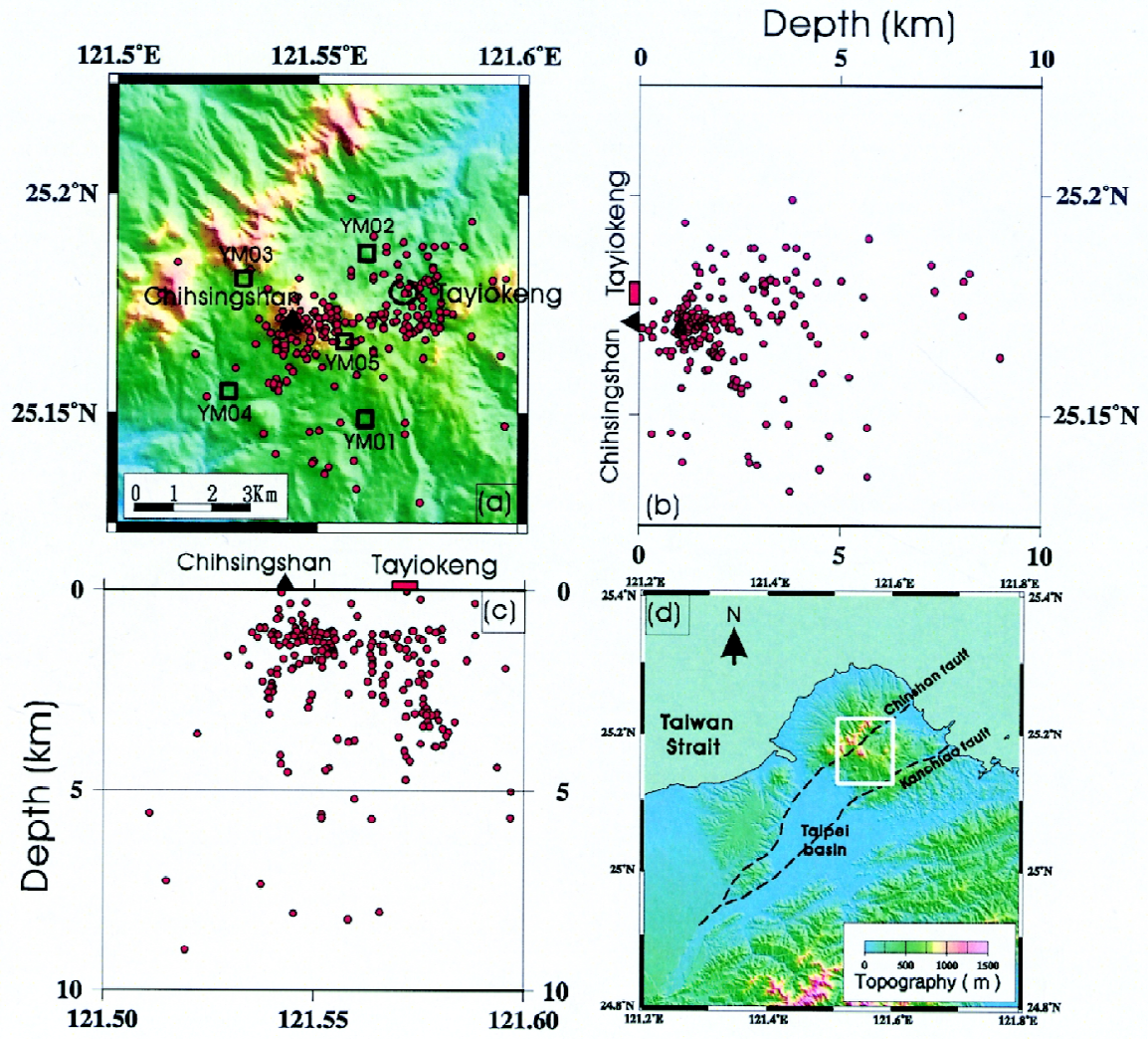

Fig. 1. (a) Seismicity (circles) and the five seismic stations (squares) are indicated on the topographic map of the Tatun volcanic area. Projections of seismicity along (b) the E-W and (c) the N-S cross-sections are shown. (d) Topographic map of northern Taiwan with the two major faults, the Chinshan and Kanchiao faults, through the Tatun volcanic area are marked by dashed lines. The box shows the Tatun volcanic area given in Fig. (a). 
True that the Tatun volcanoes have been extinct for a very long time, but by virtue of new research findings, the possibility of periodic re-eruptions can be no longer ruled out. First of all, such geothermal activities as hot springs and gas fumaroles are certainly still very widespread on the surface (Chen and Wu 1971). Added to this, the volcanic evolutionary history of Taiwan shows the Tatun volcanoes could be reactivated simply on the grounds that two major eruptions have occurred in the past few million years. Finally, recent geochemical analyses of fumarole gas further show that the Helium isotopic ratios are very high (Yang 2000), indicating some magma chambers might still exist beneath the Tatun volcanoes. Such geological and geochemical observations as these suggest that active magma chambers probably lie beneath the volcano group (Song et al. 2000b).

In addition to the findings from both geological and geochemical analyses, seismic monitoring has been providing substantive evidence in support of the likelihood of volcanic magma beneath the Tatun volcanic area. In the past decade, several seismic surveys have been undertaken in the Tatun volcanic area (Yu et al. 1980; Chen and Yeh 1991; Yeh et al. 1998), with the results having shown a large number of micro-earthquakes clustered beneath some volcanoes, such as the Chihsingshan and Huandrashan (Yeh et al. 1998; Yang 2002). Strong volcanic seismicity in the Tatun area also indicates that volcanic activity might not have yet become totally extinct; however, additional positive seismic activity that characterizes active volcanoes, such as swarms and tremors, had not been detected. This is largely because not until recently has seismic activity been continuously recorded by broadband sensors.

To improve our understanding of the seismic features of the Tatun volcanic area, in this study we started with the deployment of a small-aperture seismic array in the Chihsingshan area where seismicity is often clustered in the uppermost crust. Each of the five seismic stations was installed with both short-period and broadband sensors to detect micro-earthquakes as well as any other seismic activity, like seismic tremors and harmonic oscillations. Some of our preliminary results obtained from this small seismic array are presented in this study for the purposes of shedding light on the possible seismic characteristics of active volcanoes.

\section{SEISMIC ARRAY}

In this study, we utilized a small aperture seismic array comprised of five seismic stations in the Tatun volcanic area since May 2003 (Table 1). The seismic array in this study was first designed for focusing on a small area $(5 \mathrm{~km} \times 5 \mathrm{~km})$ around the Chihsingshan volcano where micro-earthquakes were clustered between the Chinshan and Kanchiao faults, as determined by a previous seismic survey (Yeh et al. 1998). Each of the seismic stations was constructed on a concrete-platform and was completely covered with Fiber Reinforce Plastic (FRP) to protect it from possible sulfide damage, and supplied with stable AC power (110 Volts) for continuous recording. At the same time, a 90-Am battery was connected to stabilize the power system and serve as an alternative source in case of an emergency power outage. Each seismic station was installed with both a short-period sensor (Lennartz LE3D, with a dominant frequency of $1 \mathrm{~Hz}$ ) and a broadband sensor (Glap-30, period of up to 30 seconds) to record seismic signals generated by micro-earthquakes as well as any other possible long-period seismic tremors in 
the Tatun volcanic area. All seismograms have been continuously sampled at a rate of 100 points per second and these data stored in two hard disks at each station with a full memory of $20 \mathrm{G}$-byte. The timing system at each station is automatically synchronized by satellite signals from the Global Position System (GPS). These seismic data are frequently retrieved about once a month while regular system maintenance is going on.

Table 1. Location of the five seismic stations in the Tatun volcanic area.

\begin{tabular}{|c|c|c|c|}
\hline Stations & Longitude (E) & Latitude (N) & Altitude (m) \\
\hline $\begin{array}{c}\text { YM01 } \\
\text { (Chukaoling) }\end{array}$ & $25^{\circ} 08^{\prime} 48.0^{\prime \prime}$ & $121^{\circ} 34^{\prime} 12.8^{\prime \prime}$ & 488 \\
\hline $\begin{array}{c}\text { YM02 } \\
\text { (Chihku) }\end{array}$ & $25^{\circ} 11^{\prime} 04.4^{\prime \prime}$ & $121^{\circ} 34^{\prime} 13.2^{\prime \prime}$ & 521 \\
\hline $\begin{array}{c}\text { YM03 } \\
\text { (Machao) }\end{array}$ & $25^{\circ} 10^{\prime} 44.8^{\prime \prime}$ & $121^{\circ} 32^{\prime} 22.5^{\prime \prime}$ & 702 \\
\hline $\begin{array}{c}\text { YM04 } \\
\text { (Lioku) }\end{array}$ & $25^{\circ} 09^{\prime} 12.2^{\prime \prime}$ & $121^{\circ} 32^{\prime} 09.8^{\prime \prime}$ & 401 \\
\hline $\begin{array}{c}\text { YM5 } \\
\text { (Renhsuiken) }\end{array}$ & $25^{\circ} 09^{\prime} 52.9^{\prime \prime}$ & $121^{\circ} 33^{\prime} 52.8^{\prime \prime}$ & 740 \\
\hline
\end{tabular}

\section{DATA PROCESSING}

To examine all possible seismic activities in the Tatun volcanic area, continuous seismograms recorded in the vertical component at each station are plotted on a daily basis. Daily seismic activities, from 0 to 24 hours in UTC time, are shown from the uppermost trace to the lowest one (Fig. 2). In total, there are 96 traces for each day, with each one showing seismograms continuously recorded every 15 minutes. Although all seismic events generated by local, regional and teleseismic earthquakes might have been recorded by this seismic network, at first, we were only focusing on micro-earthquakes in and around the Tatun volcanic area. With the aim of identifying micro-earthquakes within the Tatun volcanic area, seismic events were selected only if they complied with the following two criteria: events where (1) the arrivals of both the P- and S-waves were clearly recorded at more than three stations, and (2) the traveltime difference between the P- and S-waves at each station was less than 5 seconds.

Based on these two criteria, seismic data for possible micro-earthquakes were extracted from the raw data and transferred to the Seismic Analysis Code (SAC) format by using the available software (PPK) provided by SAC for the later picking process. The arrivals of both the $\mathrm{P}$ - and S-waves were picked with different levels of $(\mathrm{Q})$ ranging from 0 to 4 based on the uncertainty of arrivals (Lee and Stewart 1980). The impulsive arrivals of better quality were given by smaller levels. More specifically, the best arrivals with an uncertainty of less than 


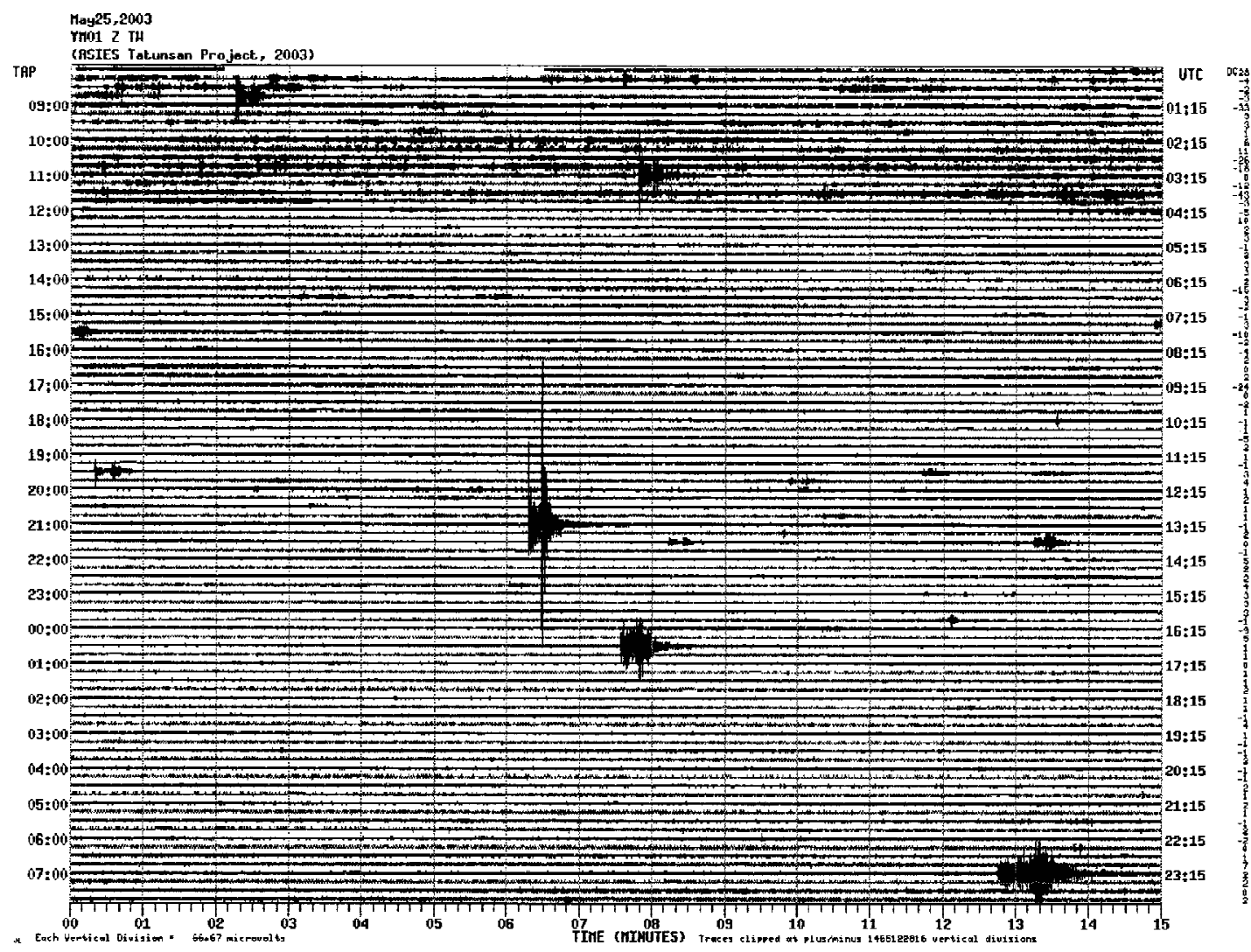

Fig. 2. Example of 24-hour seismograms recorded in vertical component at one station (YM01). Each trace shows seismic records for a 15-minute period. Local (Taipei) and UTC times are respectively marked on left and right hand sides.

0.02 seconds were given the highest level of 0 . Against this, the poorest ambiguous arrivals with an uncertainty of greater than 0.1 seconds were given the lowest level of 4 . The relative weights $\mathrm{W}$ used to further locate earthquakes as related to quality $(\mathrm{Q})$ were designated by the following relationship: $\mathrm{W}=1-\mathrm{Q} / 4$. In other words, a full weight of $100 \%$ corresponds to $\mathrm{Q}=$ 0 , and $75 \%, 50 \%, 25 \%$ and $0 \%$ weights correspond to $\mathrm{Q}=1,2,3$ and 4 , respectively.

In addition to the arrivals of the $\mathrm{P}$ - and $\mathrm{S}$-waves, the durations of the micro-earthquakes recorded at each station were determined so as to estimate earthquake magnitude (Md) based on an empirical formula (Lee et al. 1972; Crosson 1972). The duration of a seismic signal generated by an earthquake is defined as the time interval between the onset of the first P-wave and the cut-off point when the signal amplitude was approximately twice that of the noise (Lee et al. 1972). For a given earthquake, signal duration had to be measured at as many stations as possible to ensure the reliability of the calculated local magnitudes. 
Finally, the hypocenters of the micro-earthquakes were routinely determined by using the HYPO71 computer program (Lee and Lahr 1975). Apart from the arrivals of both the P-and $\mathrm{S}$-waves as well as the durations of the signals recorded at each station, a one-dimensional velocity model (Table 2) was employed to locate the hypocenters of the micro-earthquakes within the Tatun volcanic area.

Table 2. One-dimensional P- and S-wave velocity model in the Tatun volcanoc area.

\begin{tabular}{|c|c|c|c|}
\hline Depth $(\mathrm{km})$ & P-wave $(\mathrm{km} / \mathrm{sec})$ & S-wave $(\mathrm{km} / \mathrm{sec})$ & $\mathrm{Vp} / \mathrm{Vs}$ \\
\hline$-1.0 \sim 1.0$ & 3.79 & 2.13 & 1.78 \\
\hline $1.0 \sim 2.0$ & 4.07 & 2.29 & 1.78 \\
\hline $2.0 \sim 3.0$ & 4.55 & 2.56 & 1.78 \\
\hline $3.0 \sim 5.0$ & 5.12 & 2.88 & 1.78 \\
\hline $5.0 \sim 7.0$ & 5.39 & 3.03 & 1.78 \\
\hline $7.0 \sim 9.0$ & 5.98 & 3.36 & 1.78 \\
\hline $9.0 \sim 17.0$ & 6.10 & 3.43 & 1.78 \\
\hline $17.0 \sim 36.0$ & 6.70 & 3.76 & 1.78 \\
\hline $36.0 \sim 80.0$ & 7.80 & 4.38 & 1.78 \\
\hline
\end{tabular}

\section{PRELIMINARY RESULTS}

The preliminary results of our seismic monitoring of the Tatun volcanic area show numerous shallow micro-earthquakes, with local magnitudes (Md) smaller than 1 clustered within the study area in the May to September 2003 period (Fig. 1). Most of the micro-earthquakes are located in the uppermost crust at focal depths of less than $5 \mathrm{~km}$. Location errors for most of the micro-earthquakes are less than $100 \mathrm{~m}$ at the epicentral distance and less than $500 \mathrm{~m}$ at the focal depth (Fig. 3). Noteworthy is that one group of micro-earthquakes is highly clustered just beneath the Chihsingshan volcano, which has the highest peak $(1,120 \mathrm{~m})$ in the Tatun 
volcanic area and which has a typical volcano shape of topographic relief. These events are clustered at depths of only around $2 \mathrm{~km}$, which is just beneath the bottom of the quaternary volcanic rocks, the deepest thickness of which is $\sim 1500 \mathrm{~m}$ (Song et al. 2000a). East of this group of micro-earthquakes are some other micro-earthquakes with depths of 2 - $4 \mathrm{~km}$ which are roughly scattered around Tayiokeng, where both geothermal activity and the Helium isotopic ratios are the highest in the Tatun volcanic area (Yang 2000). For the most part, therefore, these micro-earthquakes are indicative of a seismic zone with an east-west trend and with focal depths in the east deeper than those in the west.

The detailed examination of the micro-earthquakes in spatial and temporal variations shows some micro-earthquakes often took place as swarms, or groups of earthquakes which closely
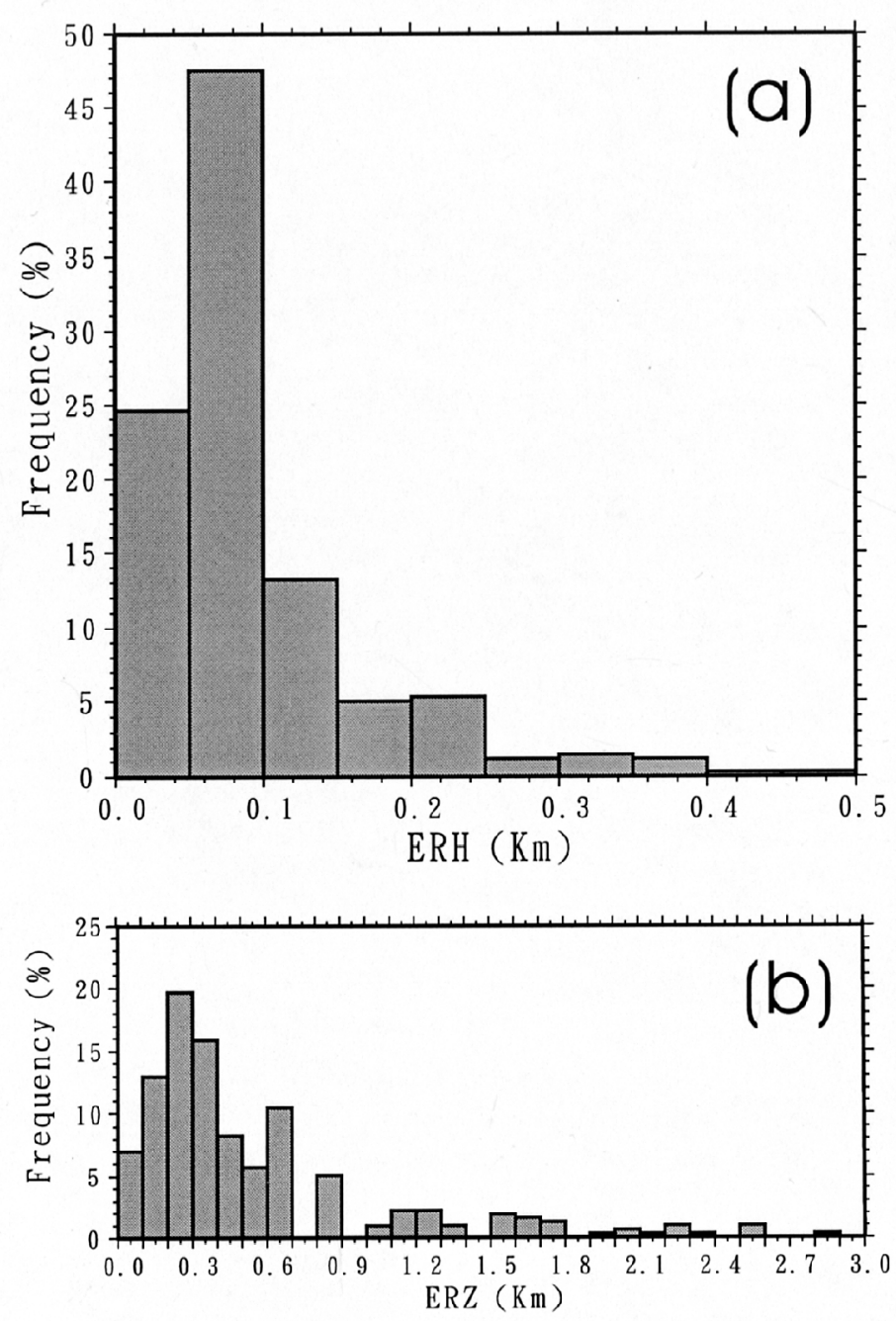

Fig. 3. Histograms of the location errors for the (a) epicenter and (b) focal depth. 
occur in time and space without a single outstanding mainshock, a phenomenon often observed in active geothermal areas such as in volcanic areas and mid-ocean ridges. For example, a series of micro-earthquakes occurred within a short period of time (only a few minutes) on June 1, 3 and 8, 2004 (Fig. 4). Consistent with the general pattern of all of the micro-earthquakes recorded here (Fig. 1), the hypocenters of these swarms are clearly clustered in two small areas (Fig. 5), one situated just beneath the Chihsingshan volcano at depths of around $2 \mathrm{~km}$, and the other at depths of $3-4 \mathrm{~km}$ beneath Tayiokeng. The locations of the microearthquakes beneath the Chihsingshan are more reliable than those of the other group because the former are located inside the seismic network.

What is particularly interesting to note is that our seismic survey in the Tatun volcanic area recorded some complex seismograms with decaying harmonic oscillations. Two groups of harmonic coda, for example, are clearly detected in the vertical component after S-waves were generated by a local earthquake (Fig. 6). Further spectral analysis shows that the frequency content in the harmonic coda is dominant at around $20 \mathrm{~Hz}$. While the detailed mechanism for generating such complicated seismograms is still unknown, the harmonic codas are substantially different from seismograms generated by typical tectonic earthquakes along tectonic faults in plate boundaries.

On top of this, strong seismic scattering is observed in the Tatun volcanic area. Seismograms generated by a regional earthquake and recorded both in the Tatun volcanic area of northern Taiwan and in the Chiayi area of southwestern Taiwan are significantly different (Fig. 7). In the Chiayi area, typical regional seismograms with clear P- and S-waves were recorded by a small aperture linear array that consisted of 18 stations (Huang 2004). Seismic energy in most of the later phases is smaller than that of the direct P- and S-waves. Contrast this with many of the later phases with large amplitudes that were recorded after both the direct $\mathrm{P}$ - and S-waves were recorded by the seismic array in the Tatun volcanic area. It is, at best, very difficult to identify the arrival of direct S-waves. Seismic energy decays very slowly for coda waves, which indicates that these coda waves did not belong to regular plane waves but rather were scattered from the strong heterogeneities in the crust medium (Aki 1969; Aki and Chouet 1975).

In addition to seismicity clustered beneath the two volcanoes as well as the unusual harmonic and scattered seismograms, a detailed examination of the seismic data in the Tatun volcanic area further shows that some seismic tremors are occasionally found at the seismic stations. For example, an unusual seismic tremor was concurrently observed in at least two stations (YM01 and YM03) on April 2, 2003 when the seismic network was first installed to examine background noises (Fig. 8). The seismic tremors with amplitudes significantly greater than background noise were continuously recorded for more than 5 hours, but these seismic tremors obviously could not have been generated by artificial noises, such as that from traffic or any other man-made source, because they were recorded in the middle of the night $(10 \mathrm{pm}$ $3 \mathrm{am})$. Also, they could not have been caused by any other unknown sources near the station site since similar tremors were simultaneously detected by at least two stations (YM01 and YM03) that were at least 5 kilometers apart. Tremors similar to these were also simultaneously recorded at all five of the stations when the seismic network was normally operated after May 15, 2003. 
(a)

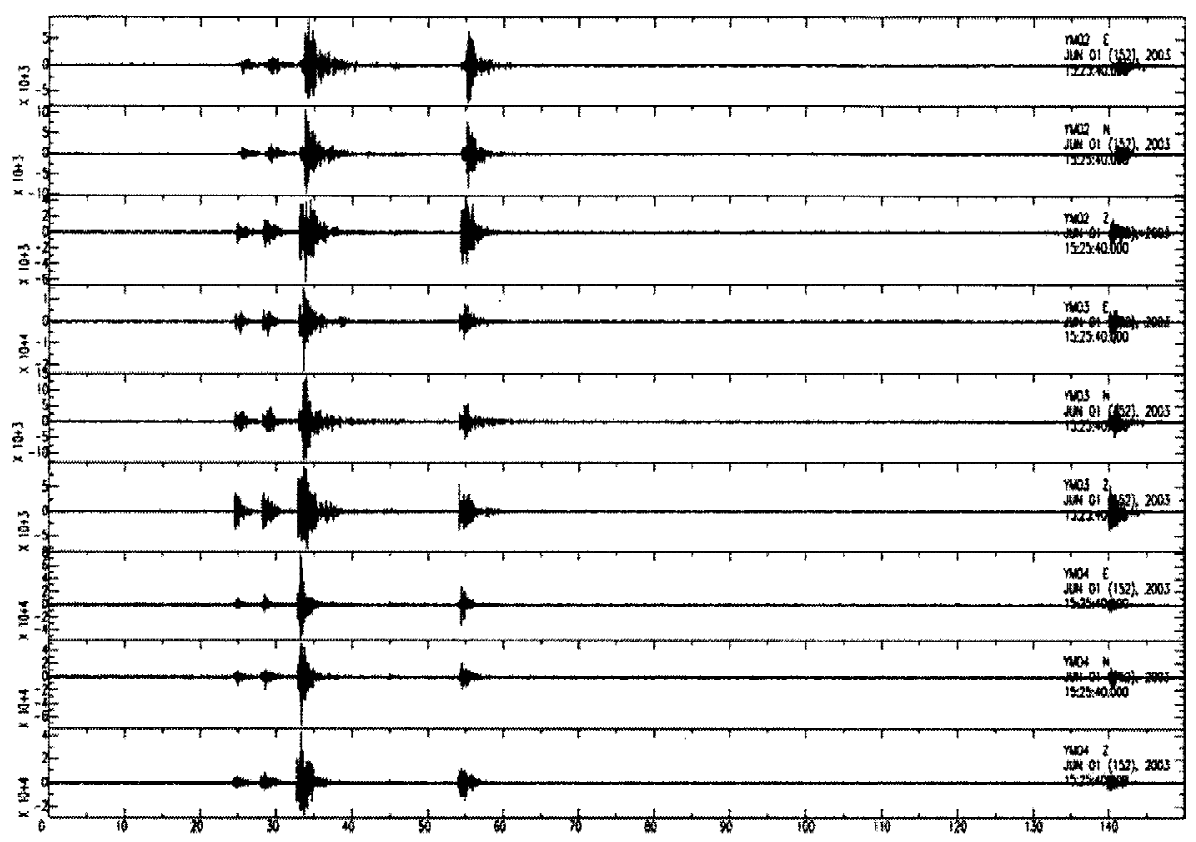

(b)

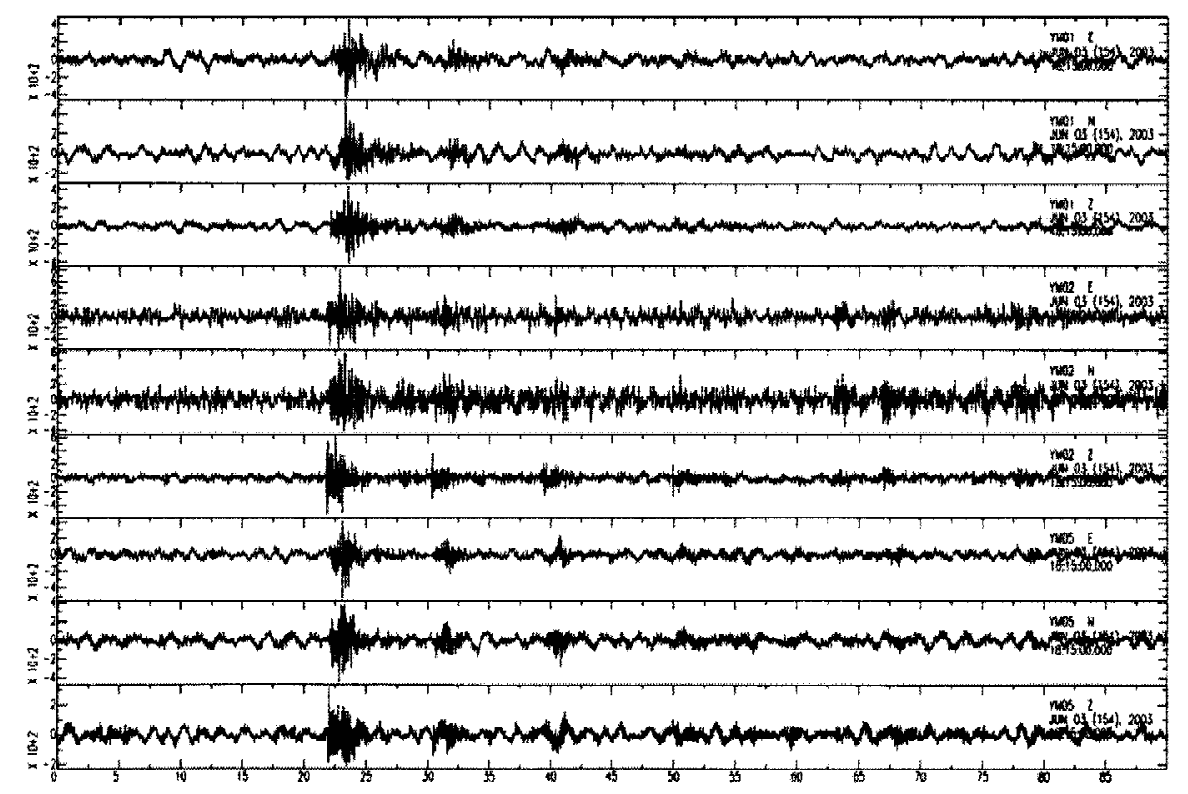

Fig. 4. Examples of swarm seismograms recorded at 3 seismic stations on (a) June 1 and (b) June 3, 2003. 

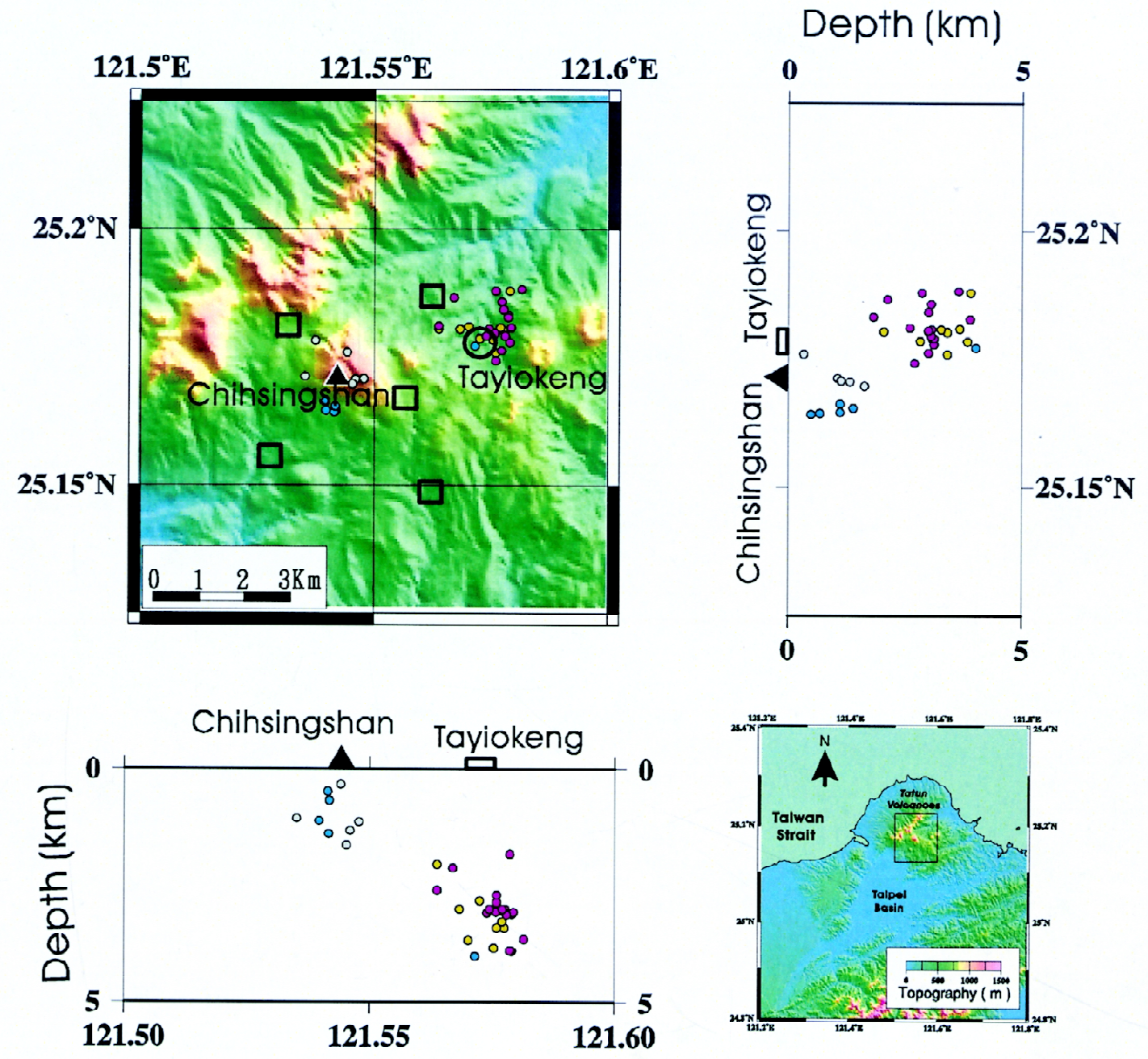

Fig. 5. Locations of the seismic stations (squares) and swarms (circles) beneath the Tatun volcanic area.

\section{DISCUSSIONS AND CONCLUSIONS}

The preliminary results from the seismic monitoring in this study convincingly show that some seismic characteristics in the Tatun volcanic area are basically similar to those in active volcanic areas in other parts of the world. First of all, the clustering of micro-earthquakes with local magnitudes of less than 1 indicates that seismic activity is still strong in the Tatun volcanic area. Since it cannot be denied that both the P- and S-waves are observed for these earthquakes, they might be classified as A-type volcanic earthquakes (Minakami 1960, 1974), which are volcanic-tectonic type, differentiating them from purely tectonic earthquakes which 


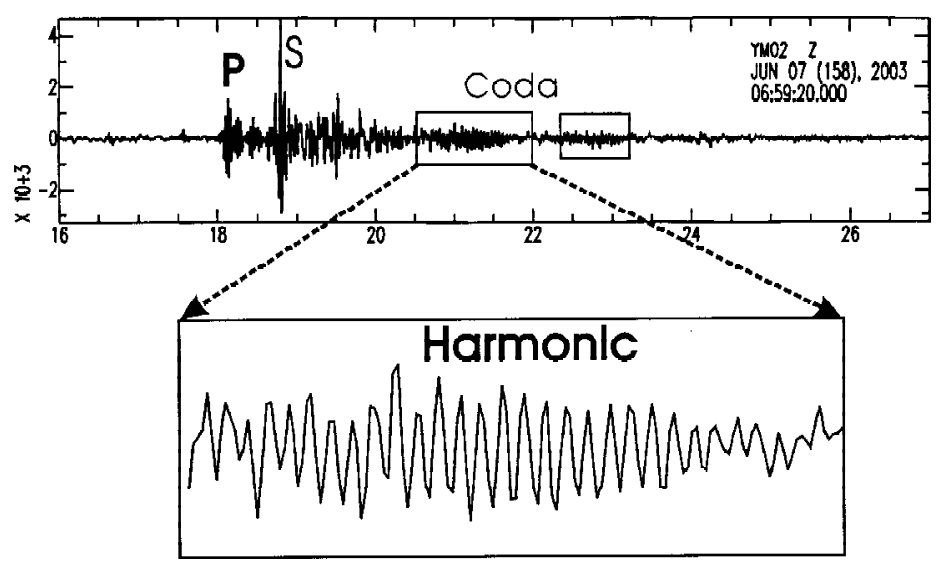

Fig. 6. Complex coda seismogram recorded at a seismic station (YM02) in the Tatun volcanic area. A harmonic section located within the small box in the seismogram is enlarged in the box below.
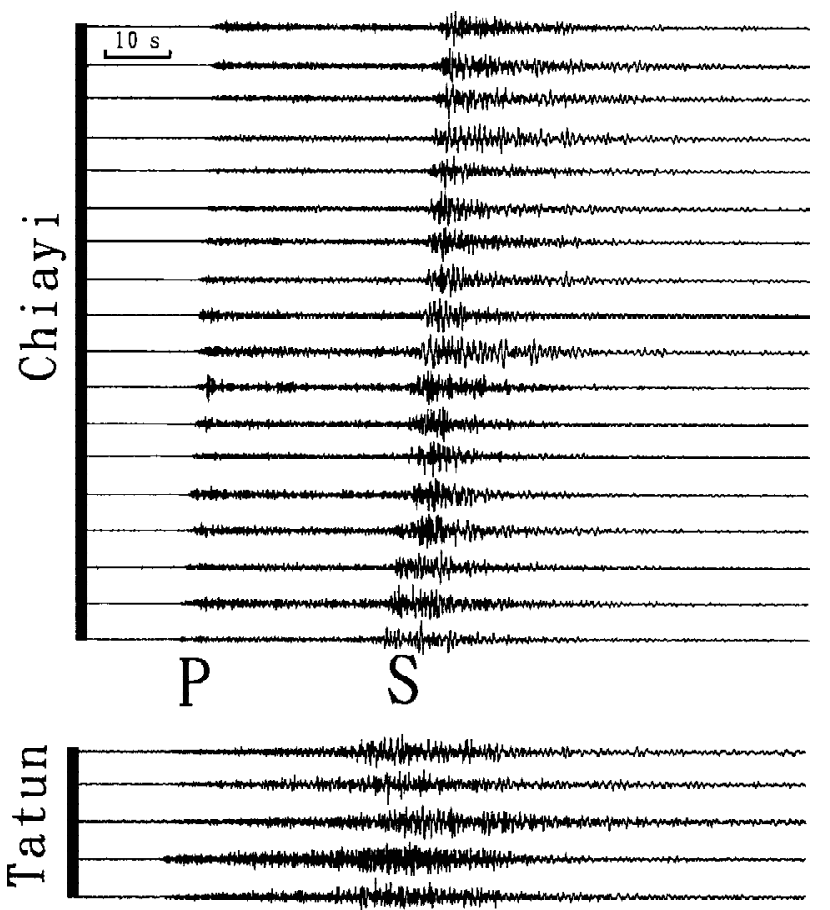

Fig. 7. Comparison of the seismograms generated by a regional earthquake and recorded in the Chiayi seismic array (the upper 18 traces) and the Tatun volcanic area (the lower 5 traces). Strong seismic scattering was recorded in the Tatun volcanic area. 
occur at plate boundaries. A-type volcanic earthquakes are commonly associated with magma movements or other thermal effects on overlying rocks, and they are often the first indicators of renewed volcanic activity (Ida 1991; Tilling and Dvorak 1993). Secondly, some seismic swarms are clustered just beneath the two most typical volcanic zones in the Tatun volcanic area. One is just beneath the Chihsingshan volcano, where the highest peak in the Tatun area is located. The clustered shallow earthquakes at $2 \mathrm{~km}$ in depth are just beneath the bottom of the quaternary volcanic rocks, the deepest thickness of which is $\sim 1500 \mathrm{~m}$ (Song et al. 2000a). The

(a)

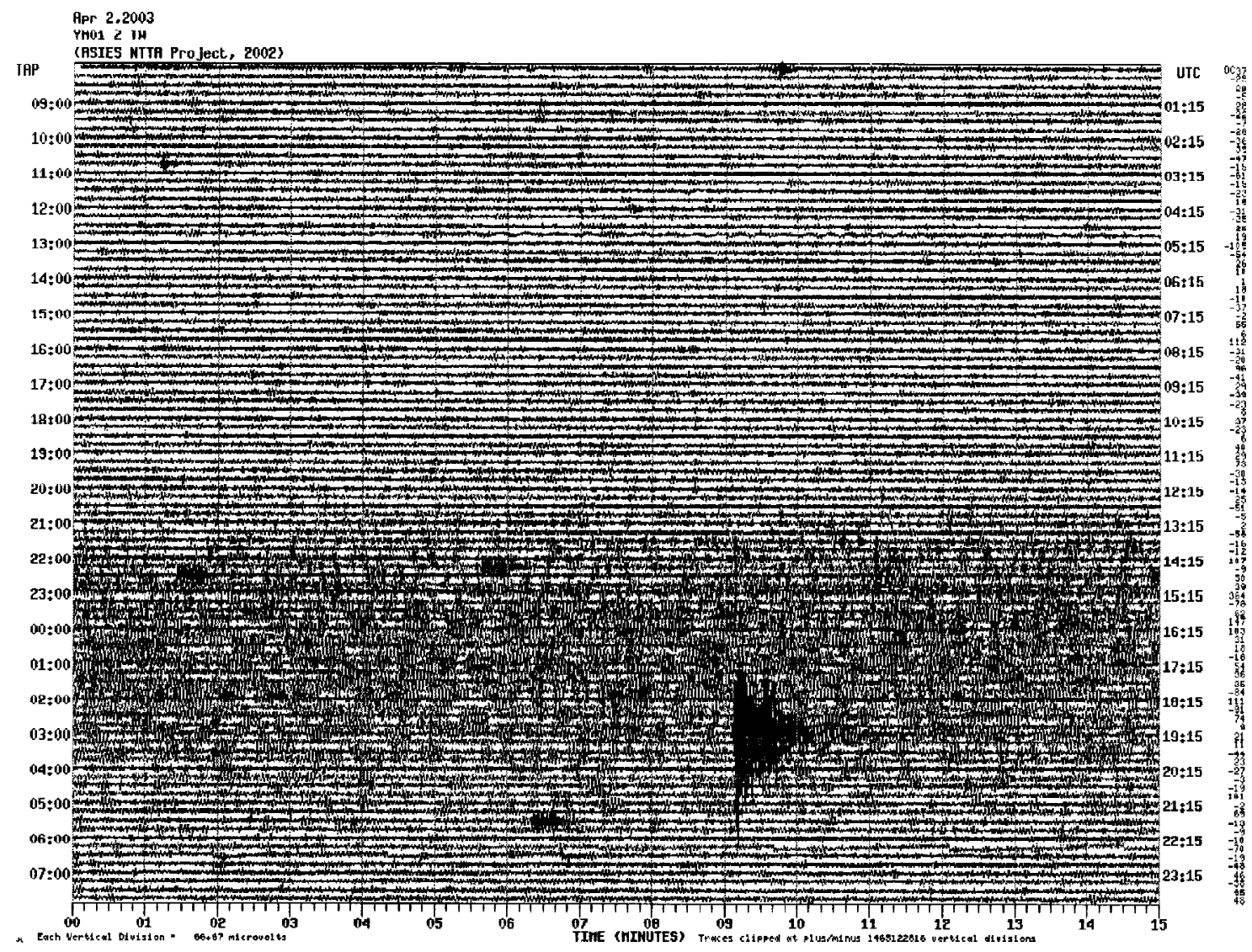

Fig. 8. Continuous seismograms recorded 24 hours at two stations, (a) YM01 and (b) YM03, on April 2, 2003. Seismic tremors continuously persisting for several hours at mid-night from around 22:00 PM to 04:00 AM at Taipei local time as recorded at two seismic stations. A distant earthquake was also recorded at two stations around the end of the seismic tremors. 
(b)

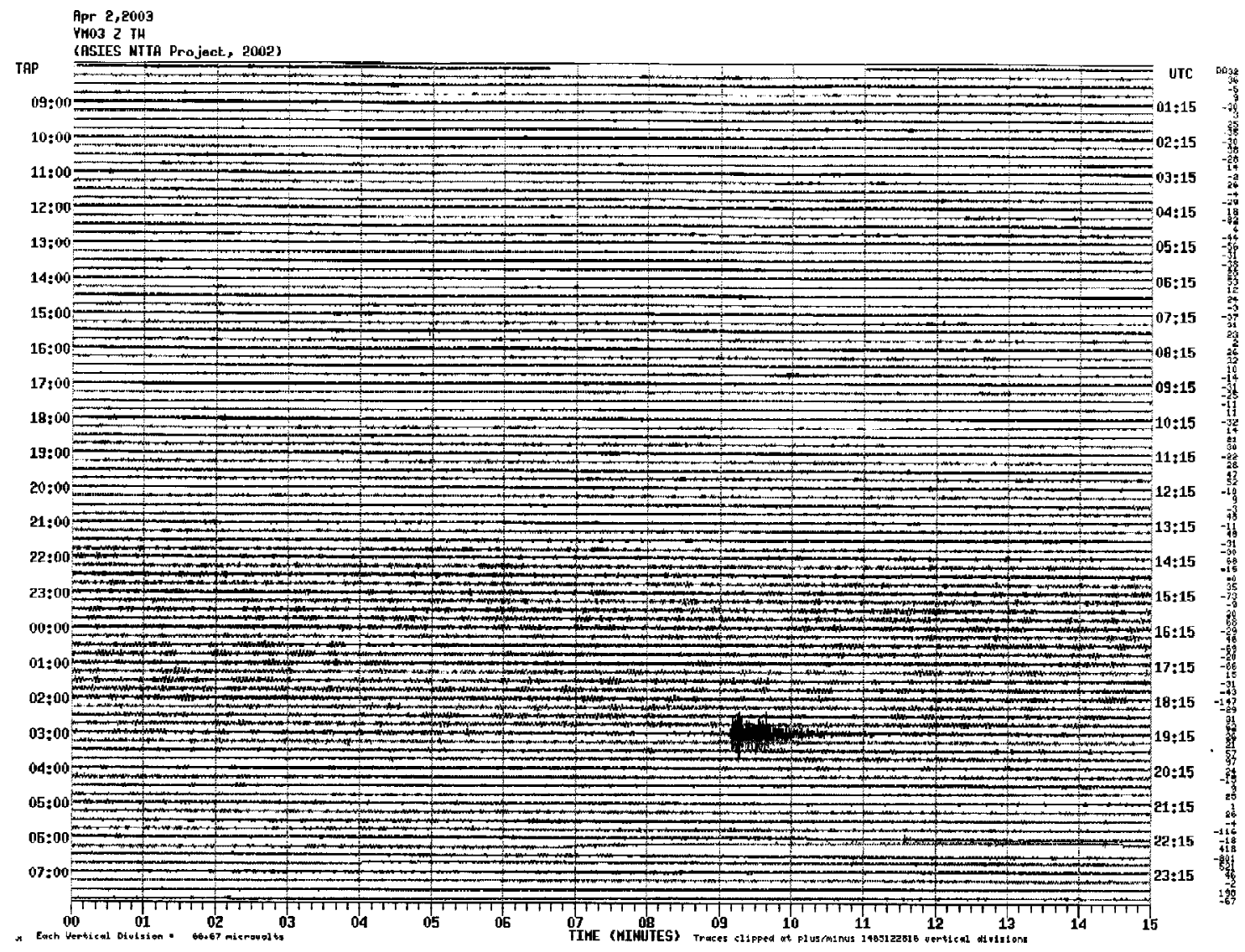

Fig. 8. Continued.

other group of earthquakes is beneath Tayiokeng, which not only has the strongest geothermal activity but also the highest isotope ratio of Helium in the Tatun volcanic area (Yang 2000). These correlative features might very well indicate the possibility of hydrothermal or magma activities in the Tatun volcanic area. Thirdly, the seismic events recorded in the Tatun volcanic area have anomalous seismograms decaying a harmonic coda, which is commonly interpreted as oscillations of a fluid-filled resonator in response to a time-localized excitation (Chouet 1986, 1996). Fourthly, the strong scattered waves generated by regional earthquakes reveal that crustal heterogeneity in the Tatun volcanic area is high. One of the best factors involved in the generation of such strong seismic scattering is the possibility of open cracks or the fluid medium beneath active volcanoes (Nishigami 1997). Finally, the existence of continuous seismic tremors recorded in the Tatun volcanic area is a feature resembling volcanic tremors that have been regarded as oscillations of some resonator in response to a sustained excitation (Chouet 2003). Whilst the possible sources of the generation of the seismic tremors and har- 
monic coda have not yet been clarified, all of the seismic characteristics reported in this study closely resemble the fundamental phenomena resulting from dynamic flow processes involving gas and liquid phases.

In light of the seismic features uncovered in this study and previous geochemical analyses, such as the Helium isotope ratios in the Tatun volcanic area (Yang 2000), we strongly suggest that further investigations be undertaken to examine the possibility of a volcanic re-eruption in the future. In this regard, one of the key questions to directly answer is, "Are there still any residual or new magma chambers beneath the Tatun volcanic area?" To examine the possibility of magma chambers beneath the volcanoes, many more detailed studies have to be performed in the future. Examples of these abound: high-resolution seismic tomography will help to image anomalous low velocities or the high Poison ratios in magma chambers; a smallaperture seismic antenna can be used to map such volcanic seismicity as tremors and swarms; moment tensor inversion can be employed to derive the source geometry and mass-transport budget of magmatic fluids; and last but not least, spectral analyses of long-period tremors have the capability of providing adequate information to determine the acoustic properties of magmatic and associated hydrothermal fluids.

Acknowledgments The first author would like to express his gratitude for the financial support from both of the Yangminshan National Park and the National Science Council, R.O.C..

\section{REFERENCES}

Aki, K., 1969: Analysis of the seismic coda of local earthquakes as scattered waves.J. Geophys. Res., 74, 615-631.

Aki, K., and B. Chouet, 1975: Origin of coda waves: source, attenuation and scattering effects. J. Geophys. Res., 80, 3322-3342.

Chen, K. J., and Y. H. Yeh, 1991: Gravity and Micro-earthquakes Studies in the ChinshanTanshui Area, Northern Taiwan. Terr. Atmos. Ocean. Sci., 2, 35-50.

Chen, C. H., and Y. J. Wu, 1971: Volcanic geology of the Tatun geothermal area, northern Taiwan. Proc. Geol. Soc. China, 14, 5-20.

Chouet, B. A., 1986: Dynamics of a fluid-driven crack in three dimensions by the finite difference method. J. Geophys. Res., 91, 967-992.

Chouet, B. A., 1996: Long-period volcano seismicity: its source and use in eruption forecasting. Nature, 380, 309-316.

Chouet, B. A., 2003: Volcano seismology. Pure Appl. Geophys., 160, 739-788.

Crosson, R. S., 1972: Small earthquakes, structure, and tectonics of the Puget Sound region. Bull. Seism. Soc. Am., 62, 1133-1171.

Huang, S. M., 2004: Crustal structures imaged from a dense linear seismic array in the Chiayi area, southwestern Taiwan, MSc Thesis, Nat. Central Univ., Taiwan.

Ida, Y., 1991: Anatomy of an eruption. Nature, 352, 571-572. 
Juang, W. S., and Chen, J. C., 1989. Geochronology and geochemistry of volcanic rocks in northern Taiwan. Bull. Geol. Surv., 5, 31-66.

Lee, W. H. K., R. E., Bennett, and K. I. Meagher, 1972: A method of estimating magnitude of local earthquakes from signal duration, USGS Open-file Rept., 28 pp.

Lee, W. H. K., and J. C. Lahr, 1975: HYPO71 (revised): A computer program for determining hypocenter, magnitude, and first motion pattern of local earthquakes, USGS Open-file Rept. 75-311, 116 pp.

Lee, W. H. K., and S.W. Stewart, 1980: Principles and applications of micro-earthquake networks. Adv. Geophys., 23, 415 pp.

Minakami, T., 1960: Fundamental research for predicting volcanic eruptions, Part I. Bull. Earthq. Res. Inst., Tokyo Univ., 38, 4497-4544.

Minakami, T., 1974: Seismology of volcanoes in Japan, In: Civetta L., P. Gaspasini, G. Luongo and A. Rapolla (Eds.), Physical Volcanology, Elservier, Amsterdam, 1-27.

Nishigami, K., 1997: Spatial distribution of coda scatterers in the crust around two active volcanoes and one active fault system in central Japan: Inversion analysis of a coda envelope. Phys. Earth Planet. Inter., 104, 75-89.

Song, S. R., Tsao, S. J., and Lo, H. J., 2000a: Characteristics of the Tatun volcanic eruptions, north Taiwan: implications for a cauldron formation and volcanic evolution.Proc. Geol. Soc. China, 43, 361-378.

Song, S. R., T. F. Yang, Y. H. Yeh, S. J. Tsao, and H. J. Lo, 2000b: The Tatun volcanogroup is active or extinct? Proc. Geol. Soc. China, 43, 521-534.

Taso, S. J., 1994. Potassium-argon age determination of volcanic rocks from the Tatun Volcano Group. Bull. Geol. Surv., 9, 137-154.

Tilling, R. I., and J. J. Dvorak, 1993: Anatomy of a basaltic volcano. Nature, 363, 125-133.

Wang, W. H., and C. H. Chen, 1990: The Volcanology and fission track age dating of pyroclastic deposits in Tatun Volcano Group. Acta Geol. Taiwanica, 28, 1-30.

Yu, S. B., and Y. B. Tsai, 1980: Micro-earthquakes and seismic tremors in the Tatun volcanic area, Open-File Rept., Inst. Earth Sci., Academia Sinica, 68 pp.

Yang, Y. H., 2002: Three-dimensional velocity structures in the Tatun volcanic area, M.Sc. Thesis, Nat. Central Univ., Taiwan, 127 pp.

Yang, T. F., 2000: The Helium isotopic ratios of fumaroles from the Tatun Volcano Group of Yangmingshan National Park, N. Taiwan. J. Nat. Park, 10, 73-94.

Yeh, Y. H., C. C. Liu, C. H. Lin, C. C. Liu, and H. Y. Yen, 1998: Geophysical monitoring of volcano actvities at Mt. Tatun, Western Pacific Geophys. Meeting, Taipei, Taiwan. 